\title{
The Application of Fluidized Bed Incineration for Sludge Innocuous Disposal in Heavy Metal Contaminated Soil Remediation
}

\author{
Xin Li
}

Key Laboratory of Environmental Protection in Water Transport Engineering Ministry of Communications, Tianjin Research Institute for Water Transport Engineering, 300456Tianjin, P.R. China

\begin{abstract}
Fluidized bed incineration is an innovative combustion technique in soil environmental remediation. It was specifically and effective for the sewage sludge remediation contaminated by heavy metals. In this paper, the sludge incineration technological process was mainly studied. There were 3 methods of sludge disposal were analysed and compared. It indicated that the process parameters and operation characteristics were thoroughly researched in sludge incineration with fluidized bed. In this article, actual combustion characteristics and parameters such as the proportion of sludge and fuel, combustion temperature, inhibition of NOx were studied. Meanwhile, it demonstrated that fluidized bed incineration technology is the key equipment proving to be a promising application of new sludge disposal technologies by fully explored.
\end{abstract}

\section{Introduction}

Sewage sludge is the solid produced during precipitation substance, especially in soil environmental remediation. The complex heterogeneous body is mainly composed of organic debris, bacteria, colloidal inorganic particles and other components of the liquid [1]. It was thick and the gum between liquid and solid matter. In heavy metal contaminated soil remediation process, the sewage sludge contains large amounts of pathogens, parasites, as well as arsenic, chromium, mercury and other heavy metals [2]. However, these pollutants were handled properly and it will cause a potential threat to the environment.

From the development of China's sewage treatment industry, the amount of sludge will be substantial growth to 50 million tons in recent years [3]. And then the sludge treatment and utilization will become a more prominent issue. At the same time, many environmental issues of heavy metal soil pollution were emerged in some region in China. All these matters need a scientific, rational sludge treatment and disposal methods. According to these matters, sludge innocuous disposal has become one of the hot researches field in environmental protection technology [4].

The utilization of sludge energy is another important green recycling technology. Fluidized bed incineration technology is currently the most common tech for these problems [5]. Because it has a very large contact area and strong combustion turbulence intensity, the sludge in the furnace have an efficient combustion reaction. Large numbers of domestic and foreign researches were carried on sludge incineration pollutant emissions in a fluidized bed. By Werther's paper, it studied that the dried sludge in a fluidized bed process NOx emission characteristics of staged combustion [6]. Ogada studied the effects of additives on the wet limestone sludge incineration process and products of incomplete combustion NOx emissions [7]. Kicherer studied the co-combustion of sludge and coal effect on NOx emissions [8]. Meanwhile, fluidized bed heat for heavy metal contaminated soil removal analytical method was rarely reported. To solve the above problems, this paper carried on different experimental conditions of combustion at different mass fraction of water in sewage sludge, combustion at different hearth temperature. Addition of limestone during combustion process and co-combustion of sludge and coal, were also studied.

\section{Introduction and comparative for sludge treatment method}

\subsection{Landfill or reclamation}

The principle of sludge treatment is a reduction, resource recovery, harmless. Their main technical routes are: landfill or reclamation, land use, drying and incineration [9]. Based on scientific site and the necessary protective treatment site, sludge landfill or reclamation is based on a traditional landfill or reclamation. Its advantage is less investment, high capacity, quick and simple technology, and easy implementation. However, due to the sludge is difficult to break down; they tend to occupy a lot of land which pollute the surrounding environment. Meanwhile, fill the pit of toxic and hazardous materials will seriously contaminate groundwater. In addition, sludge reclamation will seriously pollute the marine environment. Therefore, landfill or reclamation manner will eventually be phased out.

\subsection{Land utilization and its environmental requirements}

The sludge land utilization included improved agricultural, forest and horticulture, waste and other mines and other venues [10]. Land use of sludge has low energy consumption, recyclable sludge nutrients and other advantages. However, the sludge contains a large number of pathogens, parasites and $\mathrm{Cu}, \mathrm{Cr}, \mathrm{Hg}$ and other heavy metals and dioxins, radioactive and other harmful substances toxic biodegradable as shown in Table 1 . Therefore, the sludge must be treated by non-toxic and harmless to land utilization. Otherwise sludge toxic and hazardous materials will lead to soil or water pollution. 
Meanwhile, land use patterns have also been marginalized.

Table 1. Concentration of heavy metals in contaminated soil.

\begin{tabular}{cc}
\hline Concentration Range $\mathrm{mg} / \mathrm{kg}$ & Heavy Metal \\
\hline$<10$ & $\mathrm{Cd}, \mathrm{Co}, \mathrm{Sb}, \mathrm{Se}$ \\
$10 \sim 300$ & $\mathrm{Cr}, \mathrm{Ni}, \mathrm{Hg}, \mathrm{As}$ \\
$>300$ & $\mathrm{~Pb}, \mathrm{Cu}, \mathrm{Mn}$ \\
\hline
\end{tabular}

\subsection{Sludge incineration}

Sludge incineration is considered one of the best practical sludge treatment technologies in heavy metal contaminated soil remediation. In Europe, the United States, Japan and other developed countries, the process has become more mature for practical application. The biggest advantage is that it can quickly sludge incineration and sludge to achieve a greater degree of reduction. In addition, sludge incineration also has a processing speed, energy recycling and other prominent features. In recent years, thanks to the appropriate incineration pre-treatment process and burning means to achieve energy self-combustion of sludge. It also can meet the increasingly stringent environmental emission requirements. And then it can adequately deal with the inappropriate parts of sludge in resource utilization [11].

\section{Analysis for sludge incineration}

\subsection{Sludge incineration process}

Firstly sludge incineration can be divided into two categories: one is sent directly to the dewatered sludge incinerators, and the other is dewatered sludge drying and then burned [12]. From economic and safety considerations, drying and incineration is the higher cost of equipment. Compared with direct treatment process, although its low sludge incineration equipment costs directly, but drying incineration process can reduce energy consumption and operating costs with a better use of sludge own heat. Sludge drying and incineration process was shown in Figure 1.

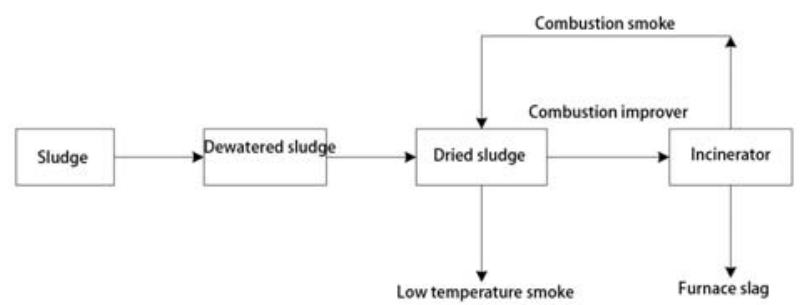

Figure 1. Flow chart for sludge drying and incineration.

The higher the moisture content of dewatered sludge (about $80 \%$ ), direct incineration require a lot of auxiliary fuel. The sludge and coal combustion flue gas emissions will lead to increased, increasing heat loss, reduce thermal efficiency. The sludge mixed with garbage burning incinerator would seriously affect combustion conditions, and the need dosing auxiliary fuel. Therefore, in order to make steady sludge incineration, it is the first use of more sludge drying, to reduce the moisture content of the sludge before incineration in advanced technology applications.

Drying process sludge treatment and disposal system is the main energy-consuming sectors. Currently it uses more fluidized bed drying technology and paddle drying technology.

\subsection{Sludge incinerator}

Sludge incinerator is the core of sludge incineration technology and equipment. They usually have a fluidized bed incinerator, multi-stage incinerator with incinerators, melting furnace, rotary kiln incinerator, Tornado incinerators. The fluidized bed incinerator is most widely used application in this process. Fluidized bed incinerator main device is a circular tower which was shown in Figure 2.

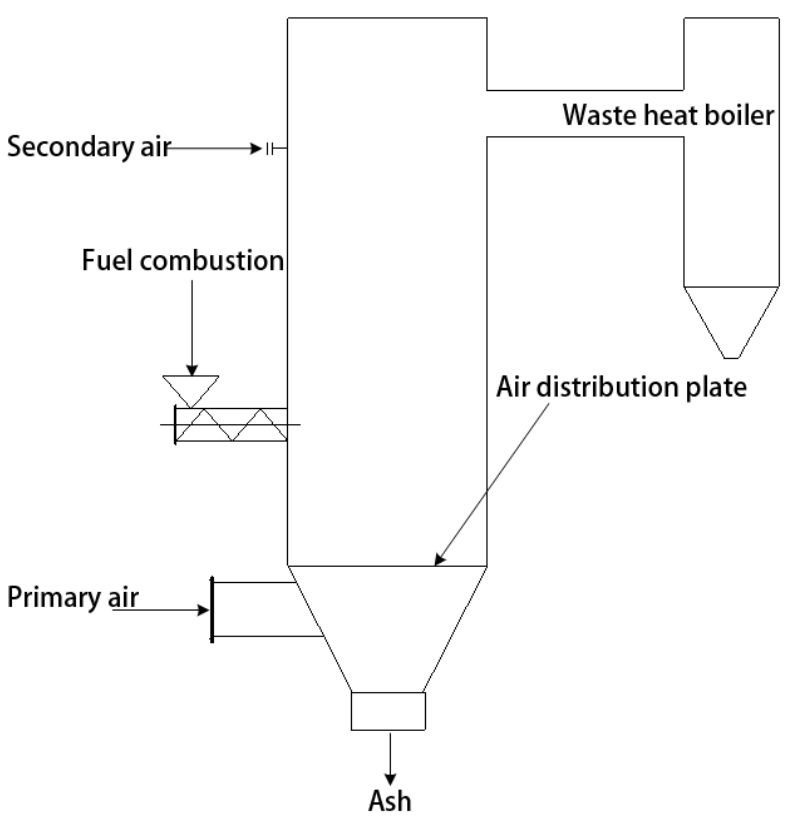

Figure 2. Schematic view of a fluidized bed sludge incinerator.

In these process, lower furnace arranged high temperature air distribution plate, refractory lining the inner wall of the tower, air distribution plate equipped with a heat-carrying medium inert particles, air distribution through the bed (also called primary air), so that the bed carrier "boiling" was a stream state.

Fuel could go into the furnace from the top or the side of the fluidized bed, violent churning and continuous circulation. By drying, mixing-crushing-mixing, and is decomposed and vaporized. Fluidized bed furnace gas generated in the upper portion of the side wall of the secondary air from the furnace tangentially blown high speed mixing incineration.

Combustion exhaust gas from the top of the incinerator, the carrier particles entrained in the exhaust gas and ash are generally used after dust collecting. The carrier may return to the fluidised bed. Bed temperature of fluidized bed operation generally does not exceed $850{ }^{\circ} \mathrm{C}$. Maintain a stable fluidized bed combustion, its temperature 
minimum cannot be lower than $750{ }^{\circ} \mathrm{C}$. In a fluidized bed, as long as the bed temperature above $680{ }^{\circ} \mathrm{C}$, volatile can catch fire and burn. High burnout rate volatiles, the reason is the main fluidized bed combustion reaction actually takes place on top of the hearth. Bed gasification fuel within the volatile components released from the bed effluent entering unbaled second combustion zone. Meanwhile, most of the remaining fuel in an internal combustion ember bed.

\subsection{Advantages of the fluidized bed}

Fluidized bed for sludge incineration has the following advantages:

(1) Huge gas-solid particles were intense mixing in the fluidized bed and a large number of inert bed material formed by surface area. It can greatly improve the heat and mass transfer rates within the fluidized bed so that it can achieve complete combustion at a relatively low temperature (370 $850{ }^{\circ} \mathrm{C}$ ) and the excess air ratio (1.25 to 1.5) under.

(2) As a heat storage tank bed material, a lot of heats were burning in a running state. So the reaction bed temperature uniformity, local overheating rarely occurs. Meanwhile, it was easy to control the temperature in the bed. Even once put more combustible waste, or sludge composition and moisture content changes, it does not produce or rapid thermal quench phenomenon.

(3) In the process contains a lot of volatile substances (such as oil sludge), it will not be as dangerous as multihearth furnace explosion.

(4) There are a large number of the fluidized beds of inert bed material, if low combustible content; incinerator can operate in accordance with an intermittent need.

(5) Material in fluidized bed thermal inertia, which can effectively reduce the thermal shock damage refractories. This feature combined with the fluidized bed temperature zone has no moving parts, so maintenance costs lower fluidized bed incinerator.

(6) In particular, fluidized bed incinerator also has its own unique advantages: wide fuel adaptability; easy to implement harmful gases such as $\mathrm{SO}_{2}$ and $\mathrm{NOx}$ control; high combustion efficiency can also be obtained; sludge incineration ash has a variety of uses.

\section{Actual combustion characteristics and parameters}

Due to the presence of moisture makes sludge incineration volatile prolonged precipitation. But also reduces the temperature inside the sludge particles. Fuel is the case of coal, because it is a completely different character and a sludge fuel. This feature also determines the discharge of sludge and coal combustion products is very different.

Impact of changes in water discharge of sludge combustion products is obvious. Because of its low moisture dry sludge, water analysing the time is shortened, volatile and rapidly precipitated on the particle surface burning. Sludge particle surface temperature rising rapidly. Dry sludge does not have clumping properties cohesion with a large number of fine particles of air into the suspension zone. These characteristics determine the dry sludge incineration $\mathrm{NO}$ and $\mathrm{CO}$ emission characteristic different from the wet sludge incineration. A feature of semi-sludge incineration is between dry and wet sludge.

As shown in figure 3, figure 4, figure 5, and figure 6; this is a very good operation data of a physical device application of fluidized bed in heavy metal Contaminated Soil Remediation [13]. The sludge moisture content increased $\mathrm{CO}$ emission concentration decreases, the concentration of $\mathrm{C}_{3} \mathrm{H}_{8}, \mathrm{C}_{6} \mathrm{H}_{14}$ and $\mathrm{C}_{6} \mathrm{H}_{5} \mathrm{NH}_{2}$ and other products of incomplete combustion of organic rose. This is due to the conversion of $\mathrm{C}_{\mathrm{x}} \mathrm{H}_{\mathrm{y}}-\mathrm{CO}$ lower sake. But moisture on sludge incineration smoke gas incomplete combustion of carbon impact is not obvious.

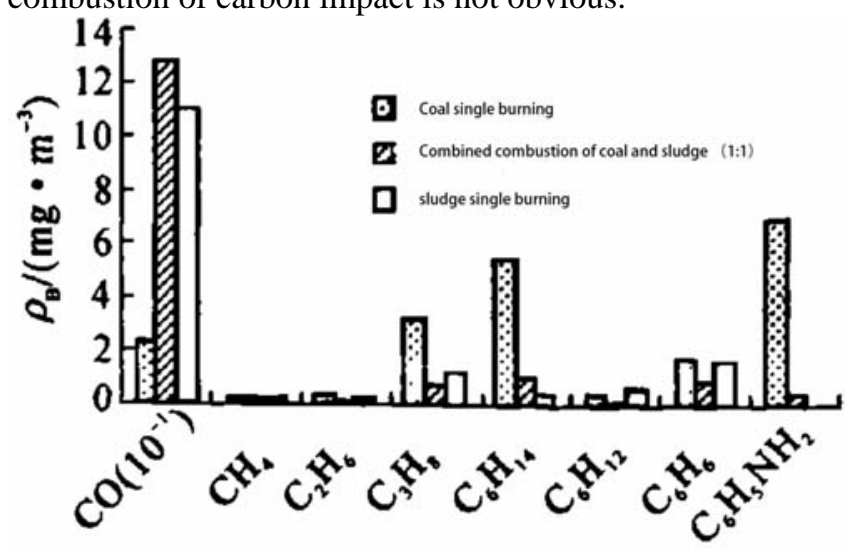

Figure 3. Incomplete combustion products (ICP) emission during combustion of sewage sludge and coal.

In a same condition, emission concentration of $\mathrm{CO}$ mass fraction of water and more sludge incineration is far less than coal emissions. The emission concentration of the organic products of incomplete combustion of coal was significantly higher than that. As the sludge moisture content is further reduced emission characteristics close to coal. When low moisture content of the sludge mass ratio of $1: 1$ and coal co-firing, there is no significant effect on the products of incomplete combustion emission characteristics of coal combustion process.

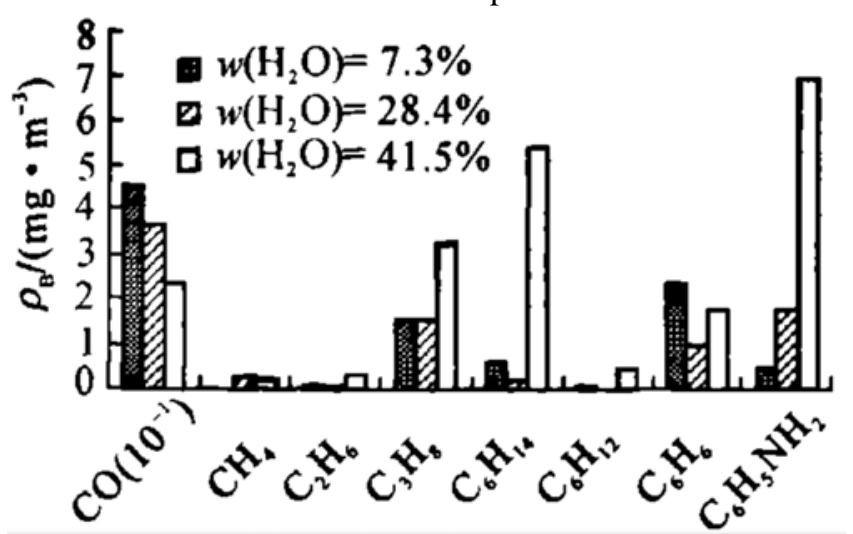

Figure 4. ICP emission during combustion of sewage sludge of different water mass fraction. 


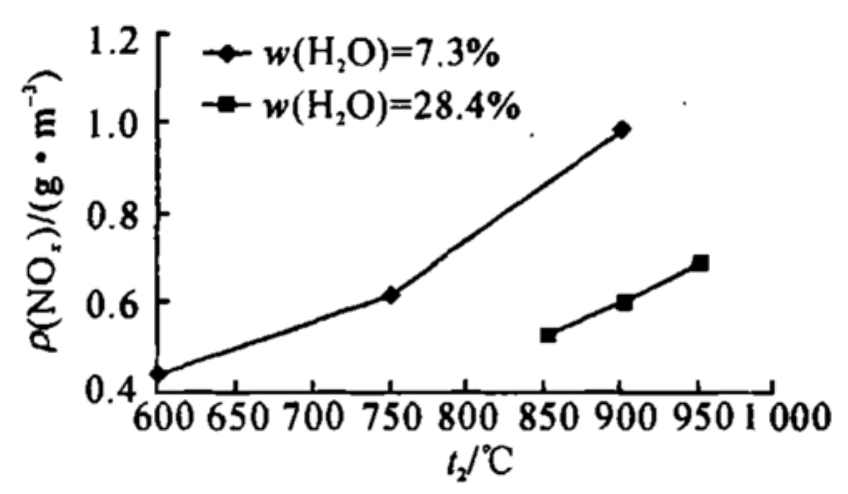

Figure 5. Influence of freeboard temperature on NOx emission.

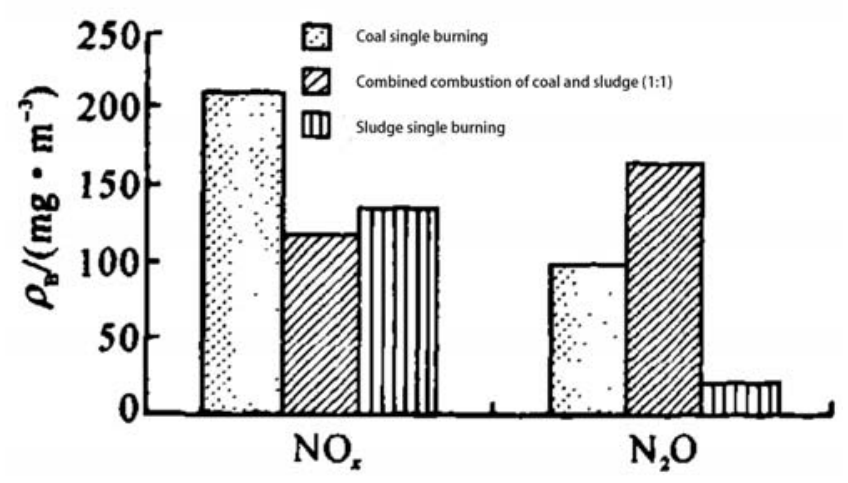

Figure 6. Effect of coal on $\mathrm{NOx}$ and $\mathrm{N}_{2} \mathrm{O}$ emission.

With the suspension segment temperature gradually increased, the concentration of NOx emissions increased by 1.5 times. Sludge fuel nitrogen to improve the NOx conversion rate. In contrast, $\mathrm{N}_{2} \mathrm{O}$ is dropped. When the sludge water content increases, NOx concentration is decreased, while $\mathrm{N}_{2} \mathrm{O}$ concentration will rise.

\section{Summary and Prospect}

Through the above analysis, fluidized bed incineration technology for sludge reduction of heavy metal pollution is a very promising environmentally friendly energy technology. These papers get the general process of the technology applications. The process parameters and structural design parameters of the main equipment were also well carried on by analysis.

This design results are ideally suited for application in the sludge reduction of heavy metal pollution and its possible improvements were as follows:

1. Cut the sludge incineration costs. Its high cost and the need to consume a lot of fuel, so that the burning of the high costs and operating expenses. It needs a new incineration process, efforts to reduce investment and operating costs, the direction of research efforts.

2. Secondary pollution sludge incinerated. Sludge combustion is not sufficient, and then it will produce poisonous gases, pollution to the environment. Combustion Technology of sludge, improve combustion efficiency, effectively eliminate the harmful gas is an important research direction sludge incineration.

3. Sludge incineration energy recovery. Recovering energy to improve energy efficiency, not only to reduce the cost of sludge incineration, but also has important energy-saving significance.

4. Suitable burning temperature, fuel blending ratio and sludge moisture content, it is very important for contaminant removal and improving the energy saving.

\section{Acknowledgement}

This work was supported by the Research of "Study of foreign soil water retention, prevent salinization, heavy metal soil remediation, soil backfill and ecological restoration technique in land reclamation. (TKS150218).

\section{REFERENCES}

[1] H. Liu, L.J. Cui, C.Q. Zhu. CIESC Journal, 66, 2694 (2015)

[2] Y.Q. Duan, Y.B. Duan, H.H. Hu. Journal of Southeast University (English Edition), 31, 188 (2015)

[3] M.Z. Su, H.B. Zhao, J.C. Ma. Journal of Combustion Science and Technology, 26, 133 (2015)

[4] J.N. Chao, J.F. Lv, H.R. Yang. Clean Coal Technology, 21, 25 (2015)

[5] D.F. Liu, B. Zhang, D.W. Sun. Energy Engineering, 3, 66 (2015)

[6] J. Werther, T. Ogada, C. Philippek. Journal of the institute of Energy, 68, 93(1995)

[7] T. Ogada, J. Werther. Fuel, 75, 617(1996)

[8] Z.M. Zheng, H. Wang, L. Yang. Journal of Southeast University (English Edition), 31, 232 (2015)

[9] Y. Cong. Science \& Technology Vision, 24, 189 (2015)

[10] S.D. Ju, S.Y. Hu, L.N. Wu. Journal of Circuits and Systems, 6, 482 (2015)

[11]Y. Chen. Sciences \& Wealth, 9, 615 (2015)

[12]Z.P. Wan, Y.F. Ma. Clean Coal Technology. 21, 121(2015)

[13]L.M. Li, H.L. Zhang, C.J. Yu, D. Li, J. Sun. Energy Engineering, 3, 61(2015) 